\title{
À guisa de apresentação
}

\author{
Antonio Augusto Passos Videira \\ Departamento de Filosofia - \\ Universidade do Estado do \\ Rio de Janeiro \\ guto@cbpf.br
}

Em uma revista como esta, que procura dar ensejo à produção de artigos nos quais os seus autores se reconheçam, não poderia faltar uma seção dedicada à publicação de textos produzidos a partir de vivências, a partir das práticas que cada um realiza no seu cotidiano. Esta seção, denominada de Relatos de Experiência, não é permanente. Ela estará presente quando houver material adequado.

Em se tratando de um número com um dossiê dedicado à universidade, seria praticamente impossível não contar com artigos contendo vivências, memórias, posicionamentos, análises sobre a presença dos seus autores no contexto desta instituição quase milenar. Todo(a) e qualquer estudante, professor(a) ou funcionário(a) universitário tem algum caso para contar, alguma opinião para proferir, algum diagnóstico para divulgar acerca do seu local de trabalho: a universidade. O entendimento da natureza dessa instituição específica e ainda insubstituível, a universidade, é produzido no seu interior, a partir de dentro, o que implica que é preciso vive-la profunda e intensamente para que se possa compreendê-la. Todo aquele que ensina, estuda ou administra na/a universidade, conhece-a intimamente. Não se pode conhecer a universidade sem vivê-la, sem experienciá-la.

Os quatro artigos agora reunidos exibem esta característica ou esta marca, apesar de serem, quando analisados a partir de aspectos descritos mais abaixo, muito diferentes entre si. Em outras palavras, os quatro artigos relatam experiências e posicionamentos distintos. Afinal, as vivências que os originam foram obtidas em tempos e locais diferentes.

O primeiro artigo foi publicado há praticamente 80 anos atrás em um periódico norte-americano (News Bulletin: Institute of International Education), hoje desaparecido. Os demais são produções originais, recentemente escritas. Não há um fio condutor que os une, à exceção do cuidado e preocupação pela 
universidade. O único ponto comum entre eles é que todos os quatro autores são professores universitários no sentido pleno desta expressão.

Guido Beck (1903-1988) nasceu no então Império Austro-Húngaro, numa cidade que se chamava Reichenberg, hoje conhecida pelo nome de Liberec. Beck, doutor em física pela Universidade de Viena, chegou ao Brasil em 1951, após ter atuado em dez países diferentes ao longo de um quarto de século, sobressaindo-se o seu período como $1^{\circ}$ assistente de Werner Heisenberg (1901-1976) na Universidade de Leipzig entre 1928 e 1932. O seu artigo descreve as suas vivências e impressões dos dois anos, entre 1935 e 1937 em que atuou nas universidades de Odessa e Kiev.

Antonio Luciano Leite Videira, nasceu em 1935 em Lisboa, vindo para o Brasil ainda criança, aqui estudou e se formou em física, em 1958, na então Universidade do Brasil, hoje Universidade Federal do Rio de Janeiro. O seu texto descreve as situações vividas com o ainda hoje pouco conhecido professor de mecânica analítica e superior, Plínio Sussekind Rocha (1911-1972), com quem conviveu entre os anos de 1957 até a morte deste último. A partir da descrição da personalidade universitária de Plínio, Videira, que estudou, pesquisou e ensinou em países como os Estados Unidos, Portugal e Itália, além do nosso, organiza e defende a sua opinião sobre o que é um autêntico professor universitário, revelando a si próprio.

Finalmente, os outros dois autores, Leonardo Rogério Miguel (1977) e André Luís de Oliveira Mendonça (1972), são ambos nascidos na cidade do Rio de Janeiro, onde realizaram toda a sua formação em filosofia na Universidade do Estado do Rio de Janeiro. A inserção de ambos no tecido universitário como professores ocorreu recentemente, já no Governo de Dilma Roussef (2011-2015). São textos de jovens acadêmicos que ainda procuram construir os caminhos adequados para a realização da sua tarefa de ensinar e formar a partir do questionamento da realidade universitária, profundamente modificada com o início das chamadas cotas, políticas inclusivas destinadas a grupos com alguma fragilidade social.

Muito mais poderia ser escrito para introduzir os autores ou artigos. Todos eles contem opiniões solidas e interessantes. Todos eles são escritos a partir de dentro: são genuínos. Apenas esta característica já os torna merecedores de nossa atenção e do nosso respeito. Afinal, mais do que o conhecimento específico, ou especializado, o que constitui um verdadeiro professor é o seu amor pelo conhecimento e pelos estudantes. 